\title{
Phenolic acid and DNA contents of micropropagated Eryngium planum L.
}

\author{
Barbara Thiem • Małgorzata Kikowska • \\ Aldona Krawczyk • Barbara Więckowska · \\ Elwira Sliwinska
}

Received: 9 October 2012/Accepted: 8 March 2013/Published online: 21 March 2013

(C) The Author(s) 2013. This article is published with open access at Springerlink.com

\begin{abstract}
A protocol for in vitro production of genetically uniform populations of the medicinal plant Eryngium planum, rich in selected phenolic acids, has been established. Shoot-tips were collected from axenic seedlings and grown on a Murashige and Skoog basal medium supplemented with 6-Benzyladenine (BA) and Indole-3-acetic acid (IAA). The highest shoot proliferation efficiency (17 shoots per explant) was obtained when $1.0 \mathrm{mg} \mathrm{L}^{-1} \mathrm{BA}$ and $0.1 \mathrm{mg} \mathrm{L}^{-1}$ were added. Proliferating shoots were rooted and transferred to soil ( $89 \%$ frequency of survival). Flow cytometric analysis of intact (field-grown) and microrpropagated plants revealed that all plants were uniform in genome size and had similar DNA contents. Thin-layer chromatography (TLC) analysis
\end{abstract}

\section{B. Thiem $(\square) \cdot$ M. Kikowska}

Department of Pharmaceutical Botany and Plant Biotechnology,

K. Marcinkowski University of Medical Sciences, 14 Św. Marii

Magdaleny Str., 61-861 Poznań, Poland

e-mail: bthiem@ump.edu.pl

M. Kikowska

e-mail: kikowska@ump.edu.pl

\section{A. Krawczyk}

Quality Control Laboratory of Phytopharm Klęka S.A.,

Klęka 1, 63-040 Nowe Miasto nad Wartą, Poland

e-mail: Aldona.Krawczyk@europlant-group.pl

B. Więckowska

Department of Computer Science and Statistics,

K. Marcinkowski University of Medical Sciences, 79

Dąbrowskiego Str., 60-529 Poznań, Poland

e-mail: basia@ump.edu.pl

\section{E. Sliwinska}

Department of Plant Genetics, Physiology and Biotechnology, Laboratory of Molecular Biology and Cytometry, University of Technology and Life Sciences, Prof. S. Kaliskiego Ave. 7, 85-789 Bydgoszcz, Poland

e-mail: elwira@utp.edu.pl indicated that multiple shoots and roots from in vitro-derived plants produced high amounts of phenolic acids, primarily of rosmarinic acid (RA). Levels of phenolic acids in in vitroderived plants were similar to those of intact plants. Furthermore, high-performance liquid chromatography revealed that root cultures in liquid medium accumulated substantial levels of RA. Thus, rapid establishment of in vitro-grown organ cultures of E. planum can also serve as reliable sources for bioactive compounds.

Keywords Micropropagation · Flat Sea Holly · Phenolic acids $\cdot$ Rosmarinic acid $\cdot$ Root culture $\cdot$ Flow cytometry

\begin{tabular}{|c|c|}
\hline \multicolumn{2}{|c|}{ Abbreviations } \\
\hline 2.4-D & Dichlorophenoxy acetic acid \\
\hline FW & Fresh weight \\
\hline IAA & Indole-3-acetic acid \\
\hline IBA & Indole-3-butyric acid \\
\hline BA & 6-Benzyladenine \\
\hline $\mathrm{CA}$ & Caffeic acid \\
\hline CGA & Chlorogenic acid \\
\hline DW & Dry weight \\
\hline $\mathrm{GA}_{3}$ & Gibberellic acid \\
\hline HPTLC & High Performance Thin Layer Chromatography \\
\hline MS & Murashige and Skoog medium \\
\hline NAA & $\alpha$-Naphthaleneacetic acid \\
\hline RA & Rosmarinic acid \\
\hline RP HPLC & $\begin{array}{l}\text { Reverse Phase High Performance Liquid } \\
\text { Chromatography }\end{array}$ \\
\hline HPTLC & High Performance Thin Layer Chromatography \\
\hline
\end{tabular}

\section{Introduction}

There are approximately 230-250 species of Eryngium L. (Sea Holly), and the genus represents the largest group of 
the Saniculoideae subfamily, which is a member of the Apiaceae family. This taxon is widespread in Central Asia, America, Central and Southeast Europe, North Africa and Australia (Wörz 2005; Wörz and Diekmann 2010). There are 26 Eryngium L. species described in Flora Europaea (Tutin et al. 1968). Four of these, including Eryngium planum L. (Flat Sea Holly), are rare or protected in Poland, and grow only in restricted regions (Żukowski and Jackowiak 1995). Eryngium species are of great value for use in traditional European medicines because they contain phenolic acids, flavonoids, triterpenoid saponins, coumarin derivatives, essential oils, and acetylenes. These compounds are associated with diuretic, antidiabetic, expectorant, spasmolytic anti-inflammatory, antinociceptive, haemolytic, and antimycotic properties (Duke et al. 2002; Le Claire et al. 2005; Köpeli et al. 2006; Zhang et al. 2008; Thiem et al. 2010, 2011).

Phenolic compounds, such as rosmarinic acid (RA), an ester of caffeic acid (CA) and 3,4 dihydroxyphenyllactic acid; and chlorogenic acid (CGA), an ester of CA and quinic acid; are known for their astringent, antiviral, antibacterial, anti-inflammatory, and antimutagenic properties (Petersen and Simmonds 2003; Matkowski 2008; Gugliucci and Markowicz-Bastos 2009). They are natural antioxidants, free radicals, and metal scavengers. This makes them, and CA, interesting targets for phytochemical research in the context of human health. This research focuses on the content of these valuable compounds in E. planum, and their use as an indicator of the quality of in vitro produced materials.

Plant in vitro cultures are commonly used in the production of phytochemicals because they produce greater yields than intact plants (Amoo et al. 2012; García-Pérez et al. 2012; Szopa et al. 2012). Several in vitro methods are in use for phenolic acid production (mainly for the production of RA). These methods include suspension cultures, organ cultures, and transformed roots (Petersen and Simmonds 2003; Matkowski 2008; Kikowska et al. 2012; Krzyzanowska et al. 2012). However, there are only a few reports on the in vitro culture of Eryngium species. Currently only E. foetidum, a rare species endemic to the Caribbean, has been successfully micropropagated for medicinal and cosmetic usage (Arockiasamy and Ignacimuthu 1998; Ignacimuthu et al. 1999; Arockiasamy et al. 2002; Martin 2004; Chandrika et al. 2011).

The advantage of using in vitro culture techniques is that propagation of medicinal plants can occur under controlled conditions. However, micropropagated plants may exhibit somaclonal variation caused by polyploidization, aneuploidy, chromosome aberrations, and sequence changes (Ramulu and Dijkhuis 1986; Zhang et al. 1987; Kaeppler et al. 2000). The risk of genetic instability increases with in vitro culture time and subjection to high levels of exogenous plant growth regulators within the culture media (Philips et al. 1994; Endemann et al. 2001). Thus, control of true-to-typeness is important during tissue culture, as well as in the final products. The confirmation of genetic fidelity is of particular importance when producing biological active metabolites. Flow cytometry is a commonly used method for the confirmation of genome size stability (Thiem and Sliwinska 2003; Sliwinska and Thiem 2007; Rewers et al. 2012). We make use of this method to compare the nuclear DNA content of micropropagated plant material with that of initial plants.

The aim of this study was to develop a rapid and reproducible protocol for $E$. planum micropropagation through axillary bud proliferation. This methodology ensures genome size stability and the ability to produce selected phenolic acids in regenerated plants. To our knowledge, the genome size of this species, the in vitro culture protocol, and the capacity of regenerated plantlets to accumulate bioactive compounds have not been previously reported. The presented protocol allows harvesting of high quality raw material from micropropagated plants without a reduction in the medicinal quality and quantity of RA and CGA.

\section{Materials and methods}

\section{Plant material}

Fruits, basal leaves, and roots of intact Eryngium planum L. plants were collected from natural habitats in Poland (Lukaszewo, Kuyavian-Pomeranian province) in August 2008. The voucher specimens were deposited in the Herbarium of the Medicinal Plant Garden at the Institute of Natural Fibres and Medicinal Plants in Poznan (Poland).

To break dormancy, cleaned fruits were first stored in paper bags at $20^{\circ} \mathrm{C}$ for 30 days (warm stratification), and then kept in wet sand at $4{ }^{\circ} \mathrm{C}$ for 30 days (cold-stratification). Following this pre-treatment, the pericarp and seed coat were mechanically removed using a scalpel. Isolated embryos were washed with distilled water, dipped in $70 \%$ (v/v) ethanol for $30 \mathrm{~s}$, followed by rinsing in $20 \%(\mathrm{v} / \mathrm{v})$ commercial bleach (5\% sodium hypochlorite solution), containing $50 \mu \mathrm{L}$ of Tween 80 , for $5 \mathrm{~min}$. Finally, they were rinsed three times in sterilized double-distilled water, and placed on Murashige and Skoog (MS; Murashige and Skoog 1962) basal medium, or on MS medium supplemented with $1.0 \mathrm{mg} \mathrm{L}^{-1}$ Gibberellic acid $\left(\mathrm{GA}_{3}\right.$; SigmaAldrich; St. Louis; MO; USA). Shoot tips of 30-day-old axenic seedlings were the source of explants. Roots of in vitro plantlets were used for root culture induction. 
Table 1 Effects of BA and IAA on shoot proliferation from shoot tip explants of E. planum on MS medium after 6 weeks of in vitro culture

Mean values within a column with the same letter are not significantly different at $\mathrm{P}=0.05$ using Duncan's Multiple Range test

\begin{tabular}{lccccc}
\hline $\begin{array}{l}\text { Growth regulator }\left(\mathrm{mg} \mathrm{L}^{-1}\right) \\
\text { BA }\end{array}$ & IAA & $\begin{array}{l}\text { Explants that } \\
\text { proliferated buds }(\%)\end{array}$ & $\begin{array}{l}\text { Shoot number pe } \\
\text { explant }( \pm \mathrm{SE})\end{array}$ & $\begin{array}{l}\text { Shoot length } \\
(\mathrm{cm} \pm \mathrm{SE})\end{array}$ & $\begin{array}{l}\text { Leaf number per } \\
\text { shoot }( \pm \mathrm{SE})\end{array}$ \\
\hline 0.0 & 0.0 & $93.19 \pm 1.0^{\mathrm{d}}$ & $4.57 \pm 0.60^{\mathrm{c}}$ & $4.65 \pm 0.04^{\mathrm{a}}$ & $2.80 \pm 0.07^{\mathrm{f}}$ \\
1.0 & 0.0 & $98.36 \pm 0.55^{\mathrm{abc}}$ & $8.03 \pm 0.60^{\mathrm{b}}$ & $1.25 \pm 0.03^{\mathrm{e}}$ & $5.6 \pm 0.06^{\mathrm{a}}$ \\
1.0 & 1.0 & $99.79 \pm 0.15^{\mathrm{ab}}$ & $15.58 \pm 0.59^{\mathrm{a}}$ & $1.33 \pm 0.02^{\mathrm{e}}$ & $3.12 \pm 0.04^{\mathrm{e}}$ \\
1.0 & 0.1 & $100 \pm 0.00^{\mathrm{a}}$ & $17.10 \pm 0.60^{\mathrm{a}}$ & $1.50 \pm 0.02^{\mathrm{d}}$ & $3.99 \pm 0.04^{\mathrm{c}}$ \\
1.5 & 0.1 & $98.19 \pm 0.6^{\mathrm{bc}}$ & $8.37 \pm 0.60^{\mathrm{b}}$ & $3.40 \pm 0.03^{\mathrm{c}}$ & $3.80 \pm 0.05^{\mathrm{d}}$ \\
2.0 & 0.1 & $97.85 \pm 0.67^{\mathrm{c}}$ & $7.63 \pm 0.60^{\mathrm{b}}$ & $3.80 \pm 0.03^{\mathrm{b}}$ & $4.53 \pm 0.06^{\mathrm{b}}$ \\
\hline
\end{tabular}

Culture media and conditions

Culture media consisted of MS basal medium, liquid (root culture) or solidified with $0.8 \%(\mathrm{w} / \mathrm{v})$ agar (shoot proliferation and rooting), supplemented with $3 \%(\mathrm{w} / \mathrm{v})$ sucrose and plant growth regulators of various concentrations (Table 1-3). All plant growth regulators originated from Sigma-Aldrich (St. Louis; MO; USA). After adjusting $\mathrm{pH}$ to 5.8 , media were autoclaved at $121{ }^{\circ} \mathrm{C}$ for $20 \mathrm{~min}$ at $105 \mathrm{kPa}$. Tissue cultures were incubated in a growth chamber under a $16: 8 \mathrm{~h}$ photoperiod at $55 \mu \mathrm{mol} \mathrm{m} \mathrm{m}^{-2} \mathrm{~s}^{-1}$ light provided by cool-white fluorescent lamps, and a temperature of $21 \pm 2{ }^{\circ} \mathrm{C}$. The root cultures were maintained in darkness.

\section{Establishment of shoot cultures}

Seedling shoot tips $(0.8-1 \mathrm{~cm}$ long) were used for induction of shoot cultures. They were placed in $250 \mathrm{~cm}^{3}$ Erlenmeyer flasks containing $50 \mathrm{~cm}^{3}$ of MS medium supplemented with 6-Benzyladenine (BA; 0.5-2.0 $\mathrm{mg} \mathrm{L}^{-1}$ ) and Indole-3-acetic acid (IAA; 0.1-1.0 $\mathrm{mg} \mathrm{L}^{-1}$ ) (Table 1). After proliferating shoots, multishoots were divided into single microshoots, or clusters of 3-5 shoots, and transferred to fresh medium every 5-6 weeks. The total number of shoots, and their length, were recorded after 5 weeks of

Table 2 Effects of auxins on rooting of E. planum shoots after 6 weeks of in vitro culture

\begin{tabular}{llll}
\hline $\begin{array}{l}\text { Medium (auxins } \\
\text { concentration in } \\
\left.\text { mg L }^{-1}\right)\end{array}$ & $\begin{array}{l}\text { Rooting of } \\
\text { shoots }(\%)\end{array}$ & $\begin{array}{l}\text { Root number } \\
\text { per explant } \\
( \pm \text { SE) }\end{array}$ & $\begin{array}{l}\text { Root length } \\
(\mathrm{cm} \pm \mathrm{SE})\end{array}$ \\
\hline $1 / 2 \mathrm{MS}$ & $92.06 \pm 1.60^{\mathrm{a}}$ & $1.97 \pm 0.51^{\mathrm{b}}$ & $4.47 \pm 0.11^{\mathrm{a}}$ \\
MS & $90.83 \pm 1.72^{\mathrm{ab}}$ & $2.78 \pm 0.47^{\mathrm{ab}}$ & $4.23 \pm 0.09^{\mathrm{ab}}$ \\
MS + IAA 0.1 & $88.24 \pm 1.69^{\mathrm{ab}}$ & $3.03 \pm 0.48^{\mathrm{ab}}$ & $3.86 \pm 0.09^{\mathrm{c}}$ \\
MS + IAA 0.5 & $90.62 \pm 1.11^{\mathrm{ab}}$ & $3.10 \pm 0.53^{\mathrm{ab}}$ & $4.05 \pm 0.09^{\mathrm{bc}}$ \\
MS + IBA 0.1 & $86.09 \pm 1.39^{\mathrm{b}}$ & $3.33 \pm 0.52^{\mathrm{ab}}$ & $1.38 \pm 0.09^{\mathrm{d}}$ \\
MS + NAA 0.1 & $90.58 \pm 1.69^{\mathrm{ab}}$ & $4.34 \pm 0.53^{\mathrm{a}}$ & $0.70 \pm 0.08^{\mathrm{e}}$
\end{tabular}

Mean values within a column with the same letter are not significantly different at $\mathrm{P}=0.05$ using Duncan's Multiple Range test fifth, seventh, or eighth subculture, using at least 10 explants per medium. Half of the shoots were further multiplied via axillary buds on the same media until enough material was available for phytochemical analyses. The other half were rooted and transferred into ex vitro conditions.

Rooting of shoots and plant transfer into soil

For rooting, excised shoots were separated and transferred into half or full-strength MS medium, with or without one of the three auxins, IAA, Indole-3-butyric acid (IBA), or $\alpha$-Naphthaleneacetic acid (NAA), in concentrations ranging from $0.1-0.5 \mathrm{mg} \mathrm{L}^{-1}$ (Table 2). They were cultured in $250 \mathrm{~cm}^{3}$ Erlenmeyer flasks containing $50 \mathrm{~cm}^{3}$ of culture medium. The rooting percentage, and the number and length of roots, were recorded after 6 weeks of culture. Healthy plantlets with well-developed roots were subsequently placed in plastic pots containing a mixture of sterile soil and sand $(1: 1 \mathrm{v} / \mathrm{v})$ with $15 \%$ Perlite (Ekodarpol; Dębno; Poland), and covered with glass beakers for 10-14 days. The plantlets that developed in vitro were then transferred into the field. The survival frequency was recorded once plants had hardened and acclimatized. Some roots excised from in vitro-derived plantlets, growing on MS medium containing $0.1 \mathrm{mg} \mathrm{L}^{-1}$ IAA, were collected prior to potting for phytochemical analyses.

Table 3 Effects of auxin on E. planum root culture growth on MS medium

\begin{tabular}{lll}
\hline Auxin $\left(0.1 \mathrm{mg} \mathrm{L}^{-1}\right)$ & FW $(\mathrm{g})$ & DW $(\mathrm{g})$ \\
\hline Control (no auxin) & $18.3 \pm 1.42^{\mathrm{c}}$ & $4.7 \pm 0.21^{\mathrm{b}}$ \\
IAA & $21.8 \pm 1.52^{\mathrm{bc}}$ & $5.1 \pm 0.23^{\mathrm{b}}$ \\
IBA & $25.1 \pm 1.45^{\mathrm{b}}$ & $5.8 \pm 0.16^{\mathrm{a}}$ \\
NAA & $32.5 \pm 1.23^{\mathrm{a}}$ & $6.2 \pm 0.28^{\mathrm{a}}$ \\
\hline
\end{tabular}

Mean values within a column with the same letter are not significantly different at $\mathrm{P}=0.05$ using Duncan's Multiple Range test 
Establishment of root cultures

Root cultures were obtained from $0.8-\mathrm{cm}$ root tips of axenic plantlets, and transferred into MS liquid medium with or without one of the three auxins: IAA, IBA or NAA $\left(0.1 \mathrm{mg} \mathrm{L}^{-1}\right)$ (Table 3). The cultures were grown in $300 \mathrm{~cm}^{3}$ flasks containing $50 \mathrm{~cm}^{3}$ of culture medium, on a rotary shaker at $100 \mathrm{rpm}$, in darkness, and subcultured to fresh medium every 6 weeks. The root biomass from 5-7 passages of stable root cultures, maintained in MS medium fortified with $0.1 \mathrm{mg} \mathrm{L}^{-1}$ IAA, was collected for phytochemical analyses.

\section{Flow cytometry}

The leaves of 6-week-old seedlings, and one-year-old in vitro shoot cultures, were used for the estimation of nuclear DNA content. Samples were prepared as described by Sliwinska and Thiem (2007), using Galbraith's buffer (Galbraith et al. 1983) supplemented with $1 \%$ (v/v) PVP10 , propidium iodide (PI; $50 \mu \mathrm{g} \mathrm{cm}^{-3}$ ), and ribonuclease A $\left(50 \mu \mathrm{g} \mathrm{cm}^{-3}\right)$. Petunia hybrida 'P $\times \mathrm{Pc}^{\prime} \quad(2.85 \mathrm{pg} / 2 \mathrm{C}$; Marie and Brown 1993) was used as an internal standard. Analyses were replicated 10 times for each plant material. For each sample, 5,000-8,000 nuclei were analysed directly after preparation using a CyFlow SL (Partec $\mathrm{GmbH}$; Münster; Germany) flow cytometer equipped with a high-grade solid-state laser with green light emission at $532 \mathrm{~nm}$, long-pass filter RG 590 E, DM 560 A, and side (SSC) and forward (FSC) scatters. Histograms were analysed using FloMax (Partec $\mathrm{GmbH}$ ) software. The Coefficient of variation $(\mathrm{CV})$ of the $\mathrm{G}_{0} / \mathrm{G}_{1}$ peak of $E$. planum ranged from 3.92 to $6.03 \%$. Nuclear DNA content was calculated using the linear relationship between the ratio of the 2C peak positions Eryngium/Petunia on a histogram of fluorescence intensities.

\section{Measurement of phenolic acid content}

Plant material from in vitro cultures, shoots from shoot culture, roots of plantlets, roots from liquid culture, and the basal leaves and roots of intact plants were used for chromatographic analyses. Shoots and roots were obtained from in vitro-derived plantlets cultured on MS with $1.0 \mathrm{mg} \mathrm{L}^{-1} \mathrm{BA}+0.1 \mathrm{mg} \mathrm{L}^{-1}$ IAA, and $\mathrm{MS}$ with $0.1 \mathrm{mg} \mathrm{L}^{-1}$ IAA respectively. Roots from liquid in vitro cultures, maintained in MS supplemented with $0.1 \mathrm{mg} \mathrm{L}^{-1}$ IAA, were also phytochemically evaluated. The extracts were preliminary analysed by high performance thin layer chromatography (HPTLC) using specific spray reagents to check the presence of the main groups of secondary metabolites: phenolic acids (rosmarinic, chlorogenic, and caffeic acids), flavonoids, and complexes of saponins (Waksmundzka-Hajnos et al. 2008). The HPTLC analyses were as described previously by Thiem et al. (2010).

Qualitative and quantitative analysis of phenolic acids in methanolic extracts were performed using high-performance liquid chromatography (HPLC). Exact amounts of fresh biomass were dried $\left(60{ }^{\circ} \mathrm{C}\right.$ for $1 \mathrm{~h}$, followed by $120{ }^{\circ} \mathrm{C}$ for $24 \mathrm{~h}$ ) to a constant weight. Then, $0.2 \mathrm{~g}$ of dried and powdered shoot and root biomass was extracted three times with $15 \mathrm{~mL} 50 \%(\mathrm{v} / \mathrm{v})$ methanol for $30 \mathrm{~min}$ at the boiling point temperature of the extractive mixture under reflux. Cooled and filtered extract was then diluted with the

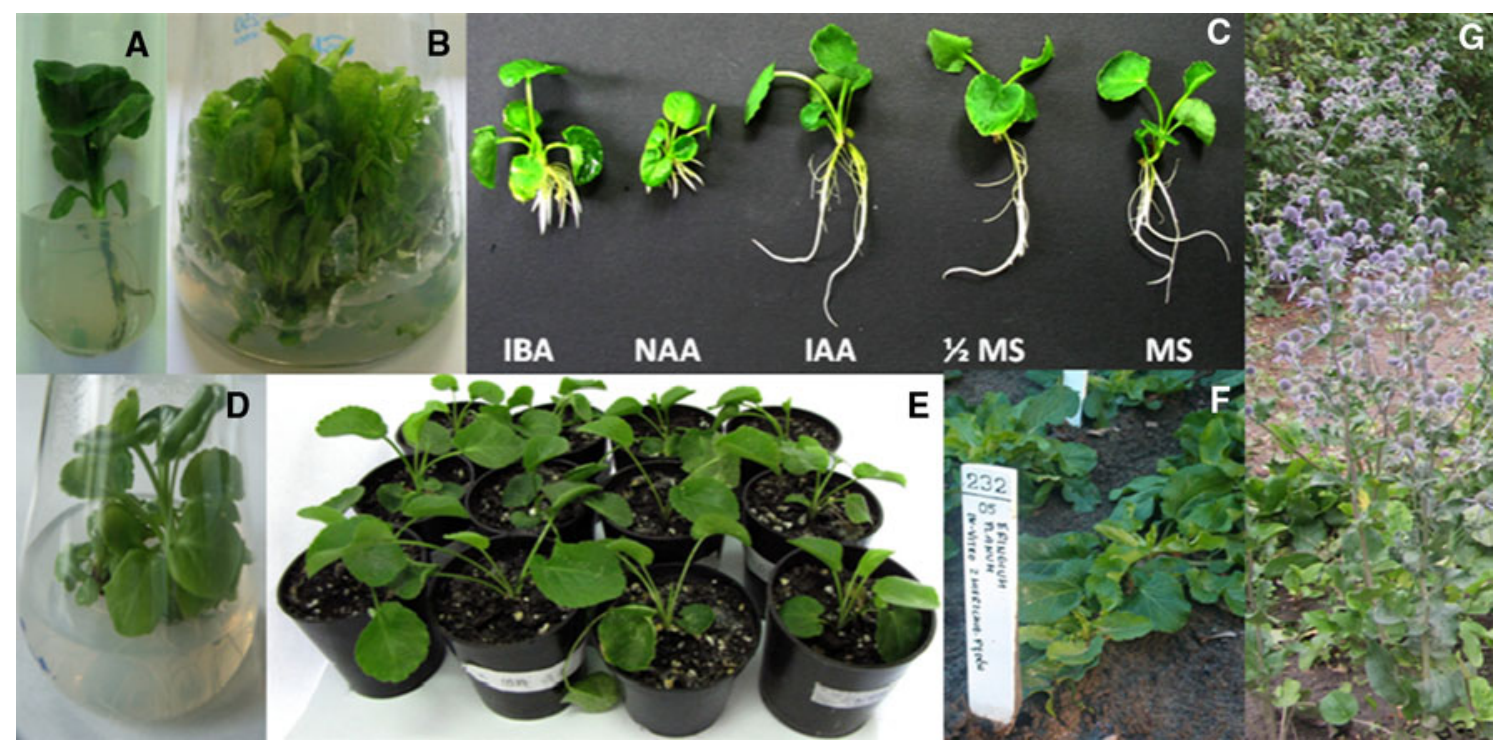

Fig. 1 a-h Micropropagation of Eryngium planum L. a 30-day old seedling. b multiplied shoots. c roots developed on varied media. d single plantlet before acclimation. e micropropagated plantlets hardened in glasshouse. $\mathbf{f}$ plants transferred to the field. $\mathbf{g}$ flowering plant 
methanol $50 \%(\mathrm{v} / \mathrm{v})$ to 50 or $100 \mathrm{~mL}$. The solution was filtered through a $0.2-\mu \mathrm{m}$ filter (Schleicher and Schuell; Dassel; Germany) and $10-\mu \mathrm{L}$ aliquots were analysed. The phenolic acid content in the methanolic extracts was determined by reverse phase high performance liquid chromatography (RP HPLC), using Merck-Hitachi (Tokyo; Japan) apparatus D-7000 coupled to photodiode array (DAD) on a LiChrospher $100250 \times 4 \mathrm{~mm}$ reversed phase column RP 18e, $5 \mu \mathrm{m}$ (Merck; Darmstadt; Germany). The solvent system was a linear gradient of acetonitrile $/ \mathrm{H}_{2} \mathrm{O}$ and phosphoric acid $\mathrm{pH} 2.2$ : acetonitrile from 15 to $60 \%$ (v/v) for $40 \mathrm{~min}$; $60 \%$ for $15 \mathrm{~min}$; from 60 to $15 \%$ for $1 \mathrm{~min}$; and $15 \%$ for $9 \mathrm{~min}$. The flow rate was $1 \mathrm{~mL} / \mathrm{min}$ and the effluent monitored by UV detection at $320 \mathrm{~nm}$. RA, CGA and CA were identified by comparison of their retention times (RT) and UV-VIS spectra with those of authentic standards. The retention times (RT) and on-line UV spectra of detected phenolic acids were identified by comparison with standards of RA (RT 13.707 min), CGA (RT $4.600 \mathrm{~min}$ ) and CA (RT $6.367 \mathrm{~min}$ ). The calibration was obtained by peak areas of RA, CGA and CA against a concentrated standard solution $(\mathrm{mg} / 100 \mathrm{~mL})$. One concentration was analysed in seven replications. The relative standard deviation of peak areas of RA, CGA and CA were 1.5, 1.3 and $1.1 \%$, respectively. Chemicals (methanol, acetonitrile, phosphoric acid) were obtained from Merck. Reference substances originated as follows: RA (purity $96.5 \%$; Sigma-Aldrich; St. Louis, MO, USA), CGA (purity $96.9 \%$; EDQM, Strasbourg; Japan), CA (purity $99.5 \%$; Fluka; Buchs; Switzerland). This investigation used $0.001 \%$ methanolic solutions of these standards. Results are means of three separate analyses from three samples of dried plant material.

\section{Statistical analysis}

The proliferation of shoots, rooting, and phenolic acid data were subjected to one-way analysis of variance (ANOVA), followed by Duncan's POST-HOC test. ANOVA followed by Student's $t$ test was used for flow cytometric results analysis. A two-sided $P$ value of 0.05 was used to determine statistical significance. All analyses were conducted using STATISTICA v. 9.1 (StatSoft, Inc. 2010).

\section{Results and discussion}

Shoot induction and proliferation

Members of the Apiaceae family produce a schizocarp fruit consisting of two one-seeded indehiscent mericarps, covered with bristles (Heywood 1978). As Apiaceae exhibit endogenous morphological dormancy their propagation by seed is difficult. The seeds germinate readily when fresh, but they become dormant soon after harvest. Therefore, a time-consuming treatment of warm-, followed by coldstratification is required to break dormancy in stored seeds (Atwater 1980; Njenga 1995). In this study, we developed a rapid in vitro clonal propagation method, using shoot tip explants derived from in vitro-grown seedlings, to increase the number of plants obtained from one seed (Fig. 1a). In a preliminary experiment, the germination of untreated seeds was $6 \%$ on MS medium, and $12 \%$ on MS medium containing $1.0 \mathrm{mg} \mathrm{L}^{-1} \mathrm{GA}_{3}$. Following stratification, and removal of pericarp and testa, germination increased to $60 \%$ on the MS basal medium, and to $89 \%$ on the $\mathrm{GA}_{3}$ supplemented MS medium. Seedlings were obtained from both types of media.

E. planum has a natural rosette growth habit with plants producing shoot clusters when grown under in vitro culture conditions (Fig. 1b). Because of difficulties involved in separating individual shoots, it is common practice to divide the shoot mass into clusters (George et al. 2008). Under our conditions, the shoot tips of in vitro cultured E. planum induced several new buds (9-12), and then proliferated into clusters of shoots. It was easier to transfer clusters of 3-5 axillary shoots to fresh medium than to transfer single shoots, and they grew much better. The addition of exogenous hormones to the MS medium resulted in varied morphogenetic responses; however, multiple shoot buds were formed in all cases (Table 1). After 6 weeks of culture, 98-100\% of explants grown on the hormone-supplemented media formed clusters of 12-15 shoots. Whereas, only $93 \%$ of the explants growing on hormone-free medium proliferated buds. The highest efficiencies of axillary bud proliferation were obtained using either a MS medium supplemented with $1.0 \mathrm{mg} \mathrm{L}^{-1} \mathrm{BA}$ and $0.1 \mathrm{mg} \mathrm{L}^{-1}$ IAA (17 shoots per explant), or a MS medium containing $1.0 \mathrm{mg} \mathrm{L}^{-1} \mathrm{BA}$ and $1 \mathrm{mg} \mathrm{L}^{-1}$ IAA (almost 16 shoots per explant). Shoot proliferation decreased significantly under higher concentrations of BA, or when no IAA was present. Higher concentrations of BA (whether applied alone, or in combination with auxin) are known to decrease the number of new microshoots per explant in other for 12 months Apiaceae such as Thapsia garganica (Makunga et al. 2003), E. foetidum (Gayatri et al. 2006), Crithmum maritimum (Grigoriadou and Maloupa 2008), Arracacia xanthorrhiza (Sliva et al. 2010), and Anethum graveolens (Jana and Shekhawat 2012). In contrast, the efficiency of shoot proliferation in Centella asiatica, and Vanasushava pedata was seen to increase in concentrations of up to $5.0 \mathrm{mg} \mathrm{L}^{-1}$ BA (Tiwari et al. 2000; Karuppusamy et al. 2006). Karuppusamy et al. (2006) also reported that IAA had a positive effect on shoot length; this was not observed in our study. BA and IAA have been shown to induce organogenesis in $E$. foetidum 
Table 4 Nuclear DNA content in leaves of E. planum obtained from seedlings and in vitro shoot culture

\begin{tabular}{ll}
\hline Plant material & DNA content $(\mathrm{pg} / 2 \mathrm{C} \pm \mathrm{SE})$ \\
\hline Leaves from seedlings & $1.805 \pm 0.0035$ \\
Leaves of shoot culture in vitro & $1.815 \pm 0.0045$ \\
\hline
\end{tabular}

Values not significantly different at $P=0.05$ (t-Student's test)

(Arockiasamy et al. 2002). In our study the shoots of E. planum exhibited high vigour, had well-expanded leaves, and unlike E. foetidum did not produce exudates (Mahamed-Yasseen 2002). When media were supplemented with a higher concentration of BA, the shoots were observed to be longer than those growing on medium containing $1.0 \mathrm{mg} \mathrm{L}^{-1} \mathrm{BA}$, even when the concentration of IAA was not changed. The highest leaf number per developed shoot occurred after culturing on MS medium with BA alone. Sporadic and very limited callus formation occurred at the base of the shoot following culture initiation (1-3 subcultures). Higher concentrations of BA were conducive for callus formation (data not shown). Similar morphogenic responses have been recorded for E. foetidum and $C$. asiatica (Ignacimuthu et al. 1999; Tiwari et al. 2000). In vitro-derived shoot-tip explants exhibited high regeneration potential with no evidence of decline even after 8-10 subcultures of mass propagation.

\section{Rooting of shoots and plant transfer into soil}

The crucial steps of micropropagation are the rooting and acclimation of in vitro plantlets. Following 60 days of culture on proliferation medium, some of the E. planum shoots spontaneously formed roots. The remaining shoots were transferred to different rooting media, either with or without supplemental auxin (Table 2). The healthy in vitroregenerated microshoots formed vigorous roots, and had a high frequency of rhizogenesis (86-92\%). The emergence of adventitious roots occurred after 2 weeks on auxincontaining medium, and 3 weeks on auxin-free medium. On all rooting media tested, microshoots underwent direct root induction, and exogenous auxin was not essential to induce roots. In contrast, in $C$. asiatica and A. xanthorrh$i z a$, no in vitro-derived shoots rooted on auxin-free MS media (Tiwari et al. 2000; Sliva et al. 2010). The roots formed by E. planum were initially whitish, but subsequently changed to dark brown when the shoots had matured. This might be due to an increased concentration of secondary metabolites. The addition of auxin, especially IBA and NAA, led to a slight increase in the number of roots, and a decrease in their length (Fig. 1c).

The rooted plantlets were successfully hardened to $e x$ vitro conditions (Fig. 1d and e), with approximately $89 \%$ of plantlets surviving the transition from tissue culture to the field. In comparison, the survival rate of A. graveolens plantlets was $60 \%$, and that of A. xanthorrhiza $62.5 \%$ (Sliva et al. 2010; Jana and Shekhawat 2012). The in vitromicropropagated plants grew well in the experimental plot, were morphologically uniform, and produced seed in the second season of vegetative growth (Fig. If and g). Furthermore, the plants were vigorous, and had well-developed roots. No detectable differences in growth characteristics were observed between in vitro-micropropagated plants and the initial intact plants.

\section{Establishment of root cultures}

When grown in phytohormone-supplemented medium, untransformed root cultures usually exhibit efficient growth of biomass, and no genetic modification of the genome occurs. Apiaceae roots have the potential to accumulate secondary metabolites, making them a good source for the production of therapeutic compounds. (Ekiert 2000; Martin et al. 2008; Murthy et al. 2008). Therefore, it is important that successful techniques for the mass culture of Apiaceae
Fig. 2 Histograms of nuclear DNA content obtained after flow cytometric analysis of the PI-stained nuclei isolated simultaneously from the leaves of Petunia hybryda (internal standard) and Eryngium planum: a-seedlings; b-regenerated plantlets
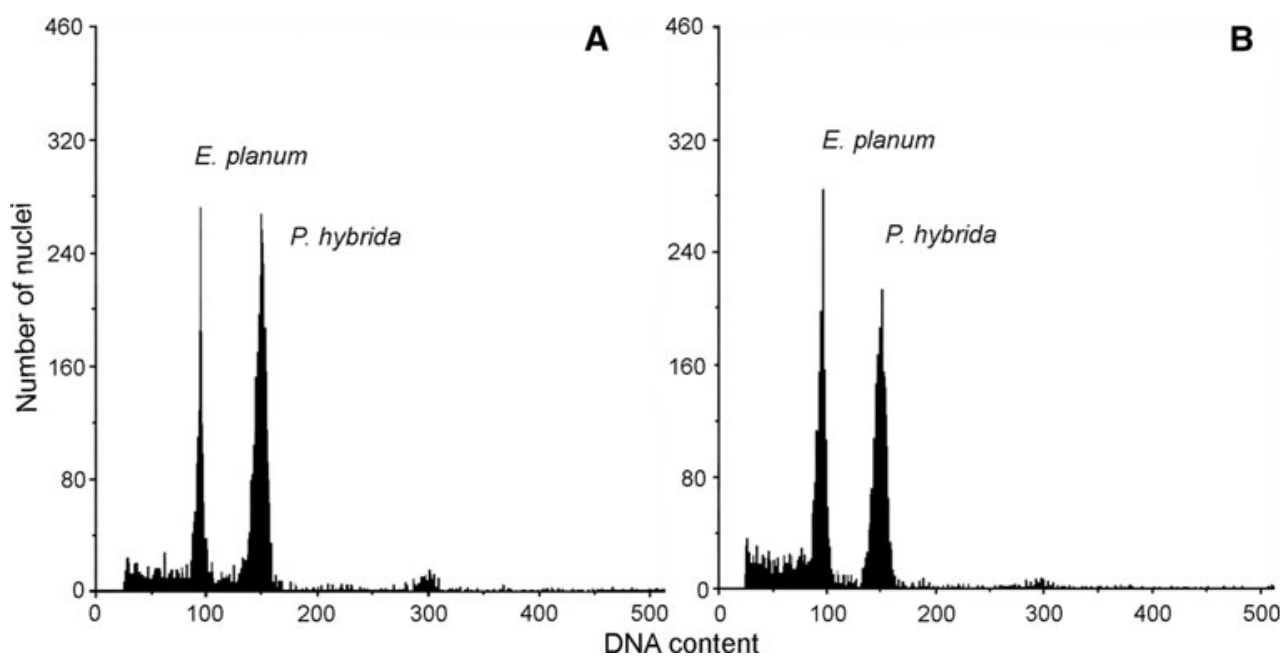
species be developed. E. planum root growth in liquid MS media was initially very slow, but became rapid after 50 days of culture. As with plantlets, the colour of the roots produced in liquid culture was age dependent; the first roots produced were initially white, but changed in colour, via golden yellow, to brown. These changes in colour may be related to an accumulation of secondary compounds (Martin et al. 2008). The roots showed high viability when liquid MS medium was supplemented with one of the three auxins, IAA, IBA or NAA. The fresh mass of roots grown in media containing auxins was greater than that of roots grown in an auxin-free control; it was greatest in rooting medium supplemented with $0.1 \mathrm{mg} \mathrm{L}^{-1}$ NAA (Table 3). The roots cultured in this medium were thicker than those maintained in medium containing IAA or IBA (data not shown). The presence of IBA in a medium led to the production of roots with many laterals. Root growth is known to be controlled by hormones (especially auxins) which affect the genetic and metabolic program of root development.

\section{Nuclear DNA content}

Confirmation of genome size stability is of particular importance in plants used as a source of therapeutic compounds because the presence, concentration, and composition of secondary metabolites should remain unchanged after micropropagation. In vitro culture often promotes genetic disturbances, and these can result in somaclonal variation; therefore, the control of genome size is desirable. Flow cytometry is widely used to establish DNA content and genome size in micropropagated medicinal plants (Thiem and Sliwinska 2003; Sliwinska and Thiem 2007; Makowczyńska et al. 2008). In this study, the regeneration of E. planum L. was performed through axillary bud proliferation without a callus phase. The 2C DNA content of leaves in the control seedlings and in shoots cultured in vitro was similar (approximately $1.81 \mathrm{pg}$, no statistical difference; Table 4; Fig. 2). Therefore, the nuclear DNA content of in vitro-propagated E. planum was maintained during long-term in vitro culture (12 subcultures). Similar genome size stability has been reported in other taxons propagated in vitro, including medical plants such as Oenothera paradoxa, Inula verbascifolia, Rubus chamaemorus, Solidago virgaurea and S. graminifolia (Winkelmann et al. 1998; Palomino et al. 1999; Sliwinska and Thiem 2007). In contrast, in vitro clones of Pueraria lobata have a lower nuclear DNA content than control seedlings (Sliwinska and Thiem 2007). Previously reported estimations of Eryngium species genome size are based on Feulgen microdensitometry, and recorded as $1.4 \mathrm{pg} / 2 \mathrm{C}$ for E. coeruleum; $2.9 \mathrm{pg} / 2 \mathrm{C}$ for $E$. variifolium; and $5.6 \mathrm{pg} / 2 \mathrm{C}$ for E. giganteum (Le Coq et al. 1978). To our knowledge, the genome size of $E$. planum has not previously been estimated.

Phenolic acid accumulation in biomass derived from in vitro cultures

Members of Apiaceae are used for the production of many important bioactive compounds, and these have wide-ranging biological and pharmacological activities (Ekiert 2000). Unfortunately, E. planum produces bioactive secondary metabolites in low quantities. This necessitates the development of alternative ways for the production of phenolic acids, especially RA, from E. planum. The use of differentiated in vitro organ cultures, especially adventitious root cultures, often results in efficient growth and facilitates the stable production of pharmaceutical compounds. Consequently, this technique has been attempted in many plants that have medicinal value (Murthy et al. 2008). In our study, the accumulation of selected phenolic acids (RA, CGA, and CA) in the shoots and roots of in vitro regenerated plantlets, and in liquid root cultures, was confirmed using HPTLC and HPLC.

Table 5 Content $\left(\mathrm{mg} \mathrm{g}^{-1} \mathrm{DW}\right)$ of three phenolic acids detected in methanolic extracts from different in vitro cultures and intact plants of $E$. planum

\begin{tabular}{|c|c|c|c|c|}
\hline \multirow[t]{2}{*}{ Plant material } & \multicolumn{4}{|c|}{ Content of phenolic acids } \\
\hline & $\mathrm{RA}( \pm \mathrm{SE})$ & CGA $( \pm$ SE $)$ & $\mathrm{CA}( \pm \mathrm{SE})$ & $\mathrm{RA}+\mathrm{CGA}+\mathrm{CA}$ \\
\hline \multicolumn{5}{|l|}{ Intact plants } \\
\hline Basal leaves & $0.081 \pm 0.007^{\mathrm{c}}$ & $0.116 \pm 0.006^{\mathrm{a}}$ & $0.003 \pm 0.000^{\mathrm{cd}}$ & $0.200 \pm 0.013^{\mathrm{c}}$ \\
\hline Roots & $0.055 \pm 0.000^{\mathrm{c}}$ & $0.019 \pm 0.000^{\mathrm{c}}$ & $0.002 \pm 0.000^{\mathrm{d}}$ & $0.076 \pm 0.000^{\mathrm{d}}$ \\
\hline \multicolumn{5}{|l|}{ In vitro cultures } \\
\hline Shoot culture (basal leaves) & $0.261 \pm 0.003^{\mathrm{b}}$ & $0.066 \pm 0.003^{\mathrm{b}}$ & $0.007 \pm 0.000^{\mathrm{b}}$ & $0.334 \pm 0.006^{\mathrm{b}}$ \\
\hline Roots of regenerated plantlets & $0.056 \pm 0.000^{\mathrm{c}}$ & $0.013 \pm 0.000^{\mathrm{c}}$ & $0.005 \pm 0.000^{\mathrm{bc}}$ & $0.074 \pm 0.001^{\mathrm{d}}$ \\
\hline Root culture & $0.595 \pm 0.035^{\mathrm{a}}$ & $0.059 \pm 0005^{\mathrm{b}}$ & $0.024 \pm 0.001^{\mathrm{a}}$ & $0.678 \pm 0.030^{\mathrm{a}}$ \\
\hline
\end{tabular}

Mean values within a column with the same letter are not significantly different at $\mathrm{P}=0.05$ using Duncan's Multiple Range test 

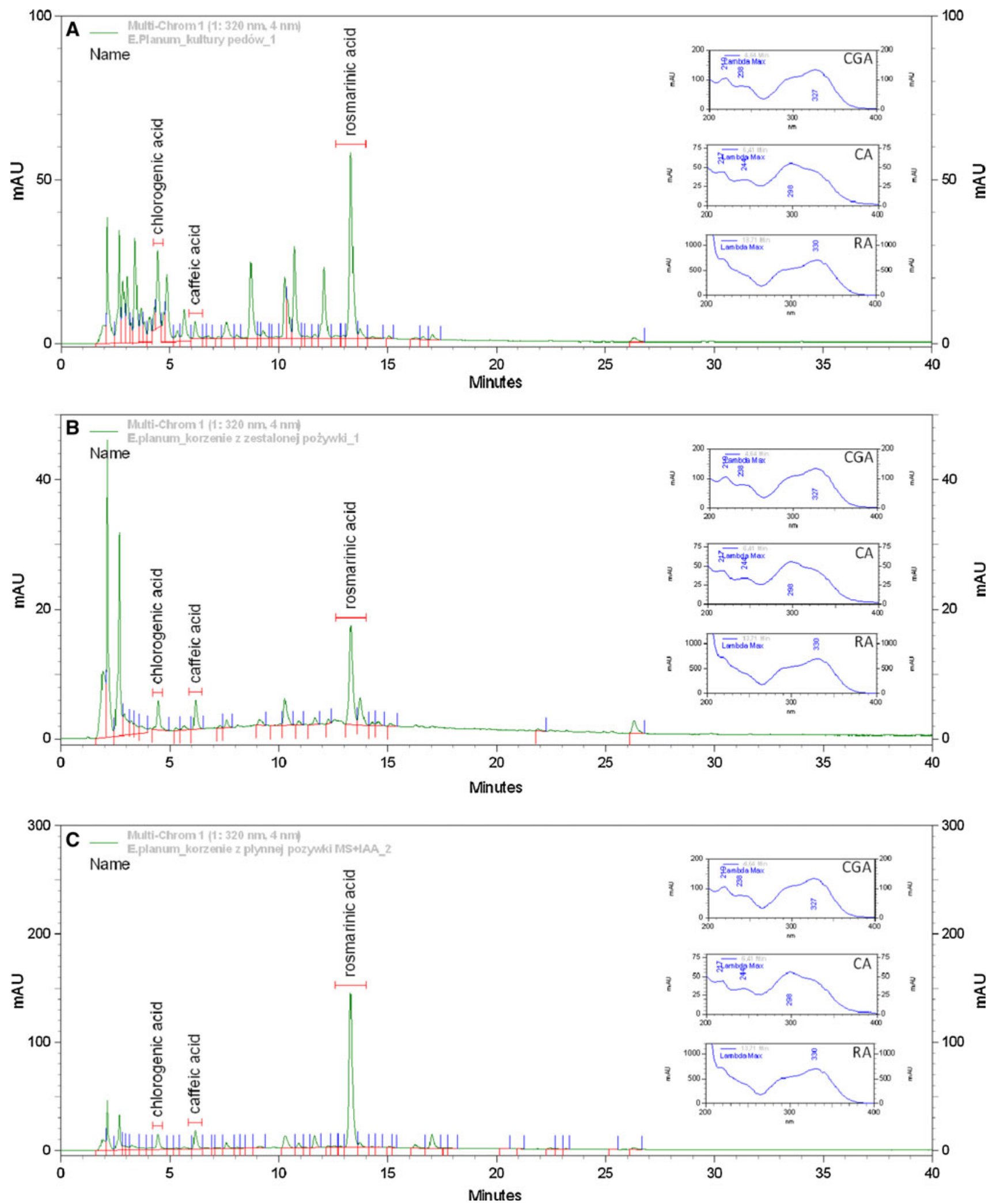

Fig. 3 HPLC chromatograms of the extracts and UV spectra of the investigated phenolic acids in $\mathbf{A}$ shoots culture in vitro $\mathbf{B}$ roots from in vitro plantlets and $\mathbf{C}$ root culture in vitro 
HPTLC analyses of ethanolic extracts from regenerated plantlets revealed that in vitro-derived plants and shoots produced phenolic acids, flavonoid compounds, and several saponins. Furthermore, phenolic acids and saponins were present in plantlet root extracts and liquid root cultures. Qualitative and quantitative HPLC analyses of the methanolic extracts from the in vitro cultures confirmed the presence of RA, CGA, and CA in all of the examined materials (Table 5; Fig. 3). Our previous phytochemical analyses had indicated that undifferentiated cultures of E. planum cell suspension and callus are able to produce selected phenolic acids (Kikowska et al. 2012). Unfortunately, the accumulation of many bioactive secondary metabolites in the cultured cells was too low to be of use in phytochemical production. This was despite our extensive efforts to optimize cell line growth and production of bioactive compounds. This is thought to be a result of metabolism being controlled in a tissue-specific manner. Cultured undifferentiated cells often partially or totally lose their biosynthetic ability to accumulate secondary products (Murthy et al. 2008). Consequently, we focused our efforts on selected phenolic acid accumulation in in vitro plant-derived organ cultures. The main phenolic compound found in most tested extracts was RA, followed by CGA, and CA. At its highest, the RA content in root cultures was ten and sevenfold higher than in the roots and basal leaves of intact plants, respectively. The use of in vitro conditions also resulted in increased RA production in the leaves of shoot cultures, in comparison with the basal leaves of intact plants. The aerial organs of plants accumulated more CGA than the roots. CA was produced in very low concentrations in all plant samples. Generally, the aerial parts of intact plants and regenerated in vitro cultures had a higher phenolic acid content than the under-ground parts. In intact plants, basal leaves accumulated twofold more phenolic acids than the roots. Similarly, the basal leaves of shoot cultures had a 4.5-fold greater phenolic acid content than the in vitro-regenerated plantlet roots. Interestingly, root cultures grown in liquid medium accumulated an almost tenfold greater amount of phenolic acids than the roots derived from in vitro-regenerated plantlets or intact plants. We observed that there was a difference in the sum of the three analysed phenolic acids in plant organs (basal leaves, or roots) when using plant material sourced from different environments (natural habitat, or in vitro cultures). The differences in analysed phenolic acid content of the organs may be a consequence of the complexities of secondary metabolite production. These processes involve biosynthesis, transport, storage, and degradation steps. The completion of secondary metabolite production depends on equilibrium between these steps, and therefore can vary between different organs and cultures (Wink 1989).

Acknowledgments This work was supported by the Ministry of Science and Higher Education, Warsaw, Poland from educational sources in 2008-2011 as grant No. NN 405 065334, and in 2011-2013 as grant No. NN 405 683340. The authors thank Professor J.D. Bewley (University of Guelph, Canada) for critical comments on the manuscript.

Open Access This article is distributed under the terms of the Creative Commons Attribution License which permits any use, distribution, and reproduction in any medium, provided the original author(s) and the source are credited.

\section{References}

Amoo SO, Aremu AO, Van Staden J (2012) In vitro plant regeneration, secondary metabolite production and antioxidant activity of micropropagated Aloe abrorescens Mill. Plant Cell Tiss Organ Cult 111:345-358

Arockiasamy S, Ignacimuthu S (1998) Plant regeneration from mature leaves and roots of Eryngium foetidum L., a food flavouring agent. Curr Sci 75:664-666

Arockiasamy S, Prakash S, Ignacimuthu S (2002) Direct organogenesis from mature leaf and petiole explants of Eryngium foetidum L. Biol Plant 45:129-132

Atwater BR (1980) Germination, dormancy and morphology of the seeds of herbaceous ornamental plants. Seed Sci Technol 8:523-573

Chandrika R, Vyshali P, Saraswathi KJT, Kaliwal BB (2011) Rapid multiplication of mature flowering plant of Eryngium foetidum $\mathrm{L}$ by in vitro technique. IJBA 3(4):114-117

Duke JA, Buts-Godwin MJ, du Cellier J, Duke PA (2002) Handbook of medicinal herbs, 2nd edn. CRC Press, New York, pp 277-278

Ekiert H (2000) Medicinal plant biotechnology: the Apiaceae family as the example of rapid development. Pharmazie 55(8):561-567

Endemann M, Hristoforoglu K, Stauber T, Wilhelm E (2001) Assessment of age-related polyploidy in Quercus robur L. somatic embryos and regenerated plants using DNA flow cytometry. Biol Plant 44:339-345

Galbraith DW, Harkins KR, Maddox JM, Ayres NM, Sharma DP, Firoozabady E (1983) Rapid flow cytometric analysis of the cell cycle in intact plant tissues. Science 220:1049-1051

García-Pérez E, Gutiérrez-Uribe JA, García-Lara S (2012) Luteolin content and antioxidant activity in micropropagated plants of Poliomintha glabrescens (Gray). Plant Cell Tiss Organ Cult 108:521-527

Gayatri MC, Madhu M, Kavyashree R, Dhananjaya SP (2006) A protocol for in vitro regeneration of Eryngium foetidum L. Indian J Biotechnol 5:249-251

George EF, Hall MA, De Klerk G-J (2008) Plant propagation by tissue culture. Springer, The Background

Grigoriadou K, Maloupa E (2008) Micropropagation and salt tolerance of in vitro grown Crithmum maritimum L. Plant Cell Tiss Organ Cult 94:209-217

Gugliucci A, Markowicz-Bastos DH (2009) Chlorogenic acid protects paraoxonase 1 activity in high density lipoprotein from inactivation caused by physiological concentrations of hypochlorite. Fitoterapia 80:138-142

Heywood VH (1978) Umbelliferae. In: Heywood VH (ed) Flowering plants of the world. Oxford University Press, Oxford, pp 219-221

Ignacimuthu S, Arockiasamy S, Antonysamy M, Ravichandran P (1999) Plant regeneration through somatic embryogenesis from mature leaves of Eryngium foetidum L. a condiment. Plant Cell Tiss Organ Cult 56:131-137

Jana S, Shekhawat GS (2012) In vitro regeneration of Anethum graveolens, antioxidative enzymes during organogenesis and RAPD analysis for clonal fidelity. Biol Plant 56:9-14 
Kaeppler SM, Kaeppler HF, Rhee Y (2000) Epigenetic aspects of somaclonal variation in plants. Plant Mol Biol 43:179-188

Karuppusamy S, Kiranmai C, Aruna V, Pullaiah T (2006) Micropropagation of Vanasushava pedata - an endangered medicinal plant of South India. Plant Tissue Cult \& Biotech 16:85-94

Kikowska M, Budzianowski J, Krawczyk A, Thiem M (2012) Accumulation of rosmarinic, chlorogenic and caffeic acids in in vitro cultures of Eryngium planum L. Acta Physiol Plant 34:2425-2433

Krzyzanowska J, Czubacka A, Pecio L, Przybys M, Doroszewska T, Stochmal A, Oleszek W (2012) The effects of jasmonic acid and methyl jasmonate on rosmarinic acid production in Menthax piperita cell suspension cultures. Plant Cell Tiss Organ Cult 108:73-81

Köpeli E, Kartal M, Aslan S, Yesilada E (2006) Comparative evaluation of the anti-inflammatory and antinociceptive activity of Turkish Eryngium species. J Ethnopharmacol 107:32-37

Le Claire E, Schwaiger S, Banaigs B, Stuppner H, Gafner F (2005) Distribution of a new rosmarinic acid derivative in Eryngium alpinum L. and other Apiaceae. J Agric Food Chem 53:4367-4372

Le Coq C, Guervin C, Hamel JL, Jolinon D (1978) La quantite d'ADN nucleaire et la garniture chromosomique chez quelques Ombelliferes. Actes 2e Sympos. Internat. Sur Ombelliferes. Contributions pluridisciplinairesa la systematique, pp. 281-291

Mahamed-Yasseen Y (2002) In vitro regeneration, flower and plant formation from petiolar and nodal explants of culandro (Eryngium foetidum L.). In Vitro Cell Dev Biol-Plant 38:423-426

Makowczyńska J, Andrzejewska-Golec E, Sliwinska E (2008) Nuclear DNA content in different plant material of Plantago asiatica L. cultured in vitro. Plant Cell Tiss Organ Cult 94:65-71

Makunga NP, Jäger AK, van Staden J (2003) Micropropagation of Thapsia garganica - a medicinal plants. Plant Cell Rep 21:967-973

Marie D, Brown SC (1993) A cytometric exercise in plant histograms, with $2 \mathrm{C}$ values for 70 species. Biol Cell 78:41-51

Martin KP (2004) Efficacy of different growth regulators at different stages of somatic embryogenesis in Eryngium foetidum L.- - a rare medicinal plant. In Vitro Cell Dev Biol-Plant 40:459-463

Martin KP, Zhang Ch-L, Hembrom ME, Slater A, Madassery J (2008) Adventitious root induction in Ophiorriza prostate: a tool for the production of camptothecin (an anticancer drug) and rapid propagation. Plant Biotechnol Rep 2:163-169

Matkowski A (2008) Plant in vitro culture for the production of antioxidants-a review. Biotechnol Adv 26:548-560

Murashige T, Skoog F (1962) A revised medium for rapid growth and bioassays with tobacco tissue cultures. Physiol Plant 15:473-497

Murthy HN, Hahn EJ, Paek KY (2008) Adventitious roots and secondary metabolism. Chinese J Biotech 24:711-716

Njenga J (1995) Production of Eryngium. N.C. Flower Growers' Bulletin 40:9-11

Palomino G, Doležel J, Cid R, Brunner I, Méndez I, Rubluo A (1999) Nuclear genome stability of Mammillaria san-angelensis (Cactaceae) regenerants induced by auxins in long-term in vitro culture. Plant Sci 141:191-200

Petersen M, Simmonds MSJ (2003) Rosmarinic acid. Phytochemistry $62: 121-125$

Philips R, Kaepler S, Olhoft P (1994) Genetic instability of plant tissue culture: breakdown of normal controls. Proc Natl Acad Sci USA 91:5222-5226

Ramulu KS, Dijkhuis P (1986) Flow cytometric analysis of polysomaty and in vitro genetic instability in potato. Plant Cell Rep 5:234-237
Rewers M, Drouin J, Kisiala A, Sliwinska E, Cholewa E (2012) In vitro regenerated wetland sedge Eriophorum vaginatum L. is genetically stable. Acta Physi Plant 34:2197-2206

Sliva Š, Viehmannova I, Vitamvas J (2010) Micropropagation and morphogenesis of Arracacha (Arracacia xanthorrhiza Bancroft). Agricult Trop et Subtrop 43:206-211

Sliwinska E, Thiem B (2007) Genome size stability in six medicinal plant species propagated in vitro. Biol Plant 51:556-558

Szopa A, Ekiert H, Szewczyk A, Fugas E (2012) Production of bioactive phenolic acids and furanocoumarins in in vitro cultures of Ruta graveolens L. and Ruta graveolens ssp. divaricata (Tenore) Gams. under different light conditions. Plant Cell Tiss Organ Cult 110:329-336

Thiem B, Sliwinska E (2003) Flow cytometric analysis of nuclear DNA content in cloudberry (Rubus chamaemorus L.) in vitro cultures. Plant Sci 164:129-134

Thiem B, Goślińska O, Kikowska M, Budzianowski J (2010) Antimicrobial activity of three Eryngium L species (Apiaceae). Herba Pol 56:52-59

Thiem B, Kikowska M, Kurowska A, Kalemba D (2011) Essential oil composition of the different parts of Eryngium planum L. Molecules 16:7115-7124

Tiwari KN, Sharma NCh, Tiwari V, Singh BD (2000) Micropropagation of Centella asiatica (L.), a valuable medicinal herb. Plant Cell Tiss Organ Cult 63:179-185

Tutin TG, Heywood VH, Burges NA, Moore DM, Valentine DH, Walters SM, Webb DA (1968) Rosaceae to Umbelliferae. In: Tutin TG (ed) Flora Europaea, vol 2. Cambridge University Press, Cambridge

Waksmundzka-Hajnos M, Sherma J, Kowalska T (2008) Thin layer chromatography in phytochemistry; Eds.; Chromatographic Science Series; CRC Press/Taylor \& Francis Group: Boca Raton pp. 99

Wink M (1989) Genes of secondary metabolism: differential expression in plants and in vitro cultures and functional expression in genetically transformed microorganisms. In: Kurz WGW (ed) Primary and secondary metabolism of plant cell cultures II. Springer, Berlin, pp 239-251

Winkelmann T, Sangwan R, Schwenkel H (1998) Flow cytometric analyses in embryogenic and non-embryogenic callus lines of Cyclamen persicum Mill: relation between ploidy level and competence for somatic embryogenesis. Plant Cell Rep 17:400-404

Wörz A (2005) A new subgeneric classification of the genus Eryngium L. (Apiaceae, Saniculoideae). Bot Jahrb Syst 126:253-259

Wörz A, Diekmann H (2010) Classification and evolution of the genus Eryngium L. (Apiaceae-Saniculoideae): results of fruit anatomical and petal morphological studies. Plant Div Evol 128:387-408

Zhang DL, Li KQ, Gu W, Hao LF (1987) Chromosome aberration and ploidy equilibrium of Vicia faba in tissue culture. Theor Appl Genet 75:132-137

Zhang Z, Li S, Ownby S, Wang P, Yuan W, Zhang W, Beasley SR (2008) Phenolic compounds and rare polyhydroxylated triterpenoid saponins from Eryngium yuccifolium. Phytochemistry 69:2070-2080

Żukowski W, Jackowiak B (1995) Endangered and threated vascular plants of Western Pomerania and Wielkopolska. Bogucki Wydawnictwo Naukowe Poznań pp 22-25:43 